University of Nebraska - Lincoln

DigitalCommons@University of Nebraska - Lincoln

Faculty Publications in Educational

Administration

Educational Administration, Department of

2019

Supporting Students Globally in Higher Education: Trends and

Perspectives for Student Affairs and Services

Rachel Gresk

Elizabeth Niehaus

Follow this and additional works at: https://digitalcommons.unl.edu/cehsedadfacpub

Part of the Educational Administration and Supervision Commons

This Article is brought to you for free and open access by the Educational Administration, Department of at DigitalCommons@University of Nebraska - Lincoln. It has been accepted for inclusion in Faculty Publications in Educational Administration by an authorized administrator of DigitalCommons@University of Nebraska - Lincoln. 


\title{
Supporting Students Globally in Higher Education: Trends and Perspectives for Student Affairs and Services
}

\author{
Osfield, K. J., Perozzi, B., Moscaritolo, L. B., \& Shea, R. (2016). \\ Supporting students globally in higher education: Trends and \\ perspectives for student affairs and services. Washington DC: \\ NASPA-Student Affairs Administrators in Higher Education. \\ 400 pp. ISBN 0931654955 (hardcover) \$39.95. \\ Reviewed by \\ Rachel Gresk, American University of Iraq, Sulaimani, \\ \& Elizabeth Niehaus, University of Nebraska-Lincoln
}

Supporting Students Globally in Higher Education (2016) provided an overview of current issues and recommendations for practice related to student affairs and services across the globe. This book is a compendium of chapters, written from a diverse and globally experienced collection of authors, that not only explores a variety of concepts around internationalization in detail (i.e., global trends, crossborder cooperation, student mobility) but challenges paradigms that have shaped the field. The concepts and ideas in this text are timely and presented with a global mindset as well as provide an example of the field's ongoing commitment to continue the conversation of global education. This especially comes across in the book's main themes that student affairs professionals must understand and promote the bene-

Published in Journal of Student Affairs Research and Practice, 56(3), 349-351.

DOI: /10.1080/19496591.2018.1545661

Copyright (C) NASPA 2019. Used by Permission. 
fits of global education and internationalization, expand their own intercultural competence, learn how to engage in cross-border collaboration, and work to sustain powerful organizations that can help all students attain a high-quality higher education.

Part 1 begins with Perozzi, Osfield, Moscaritolo, and Shea, who used Chapter 1 to establish the importance of collaborative work in the internationalization of global student affairs and services; each subsequent chapter in Part 1 contributes to our understanding of how to engage in this collaborative work. Next, Perozzi, Giovannucci, and Shea (Chapter 2) laid out the history of the "global dialogue" within the field of student affairs and services internationally through the forum of the Global Summit, which provides an opportunity for student affairs and services professionals from around the world to from collaborative networks. In Chapter 3, Heyde explored Europe's contribution to global higher education through the Bologna process and called on student services professionals to understand the impact of internationalization on increasingly diverse and mobile student populations. Seifert, Perozzi, and Li explored in Chapter 4 the variety of educational experiences and pathways that bring global student affairs and services professionals to the field, arguing that an understanding of these diverse pathways, disciplinary backgrounds, and opportunities for professional development are a critical element of effective collaboration. In Chapter 5, Shea, Gormley, Clarke, and Leary build off of Seifert and colleagues' work in Chapter 4, describing the various professional associations and opportunities for professional development for global student affairs and services practitioners.

Part 2 begins with Moscaritolo and Roberts (Chapter 6), who provided results from their research into the goals, responsibilities, and necessary competencies that unite the work of student affairs and services around the globe. They laid an important foundation for the rest of the Part 2, which focuses on the knowledge, skills, and dispositions needed for practitioners to provide quality student services. Deardorff's focus in Chapter 7 was to debunk myths about intercultural learning, especially the often-practiced assumption that students' intercultural competence can be developed through short events that bring students from different cultures together (e.g., International Night). Instead, Deardorff provided examples of how other cultures frame intercultural understanding as a way to encourage student ser- 
vices professionals to focus on meaningful and sustained programming to facilitate the long-term process of intercultural competence development. Chapters 8, 9, and 10 then described various ways that student affairs and services professionals can work to enhance their own, and their students', intercultural competence. In Chapter 8, Rogers, Cawthon, and O'Connell explored the positive impact of study abroad and international exchanges programs in student affairs and services preparation programs, not just for individual students but for student affairs and services departments within their institutions. Dieguez and El Housseini in Chapter 9 reinforced the benefits and challenges of students pursuing educational experiences abroad and provides student service practitioners with practical techniques to grow their institutions' international education experiences. Finally, in Chapter 10, Stensberg, Silva, and Medina laid out the benefits that international employment brings to professionals working in student affairs and services.

Part 3, which focuses on the need to critically examine how we are engaging globally, begins with Stryker, Witt, and Konecny (Chapter 11), who described the challenges and opportunities confronting student affairs and services professionals working globally, as international branch campuses, education hubs, and other forms of transnational education proliferate around the world. In Chapter 12, Schreiber described various models of student mobility and discussed the role of student affairs and services professionals in increasing access to mobility opportunities and ensuring that the benefits go beyond individual and institutional economic gain, instead focusing on the development of global-local consciousness. Next, Kruger et al. described in Chapter 13 the role that national and international professional associations around the world have played in fostering responsible international collaborations in research and practice. Callahan's Chapter 14 explored country-specific trends and issues in student affairs and services practice in order to help those in the field identify the similarities and differences in our work. In the end, the book's central theme, echoed in Perozzi and Shea's Chapter 15, is not just a recommendation for student affairs and services professionals to understand and promote the benefits of global education but for a conceptualized understanding that practitioners in various countries need to listen to and learn from each other. 
Beyond the exploration of concepts within global higher education, one of the strengths of this text is the media feature: its connection to the International Association of Student Affairs and Services (IASIS) website, mentioned in Callahan's Chapter 14. The website has several helpful features for student affairs and services professionals, including a current list of information on professional associations from various countries and a collection of essays from representatives around the globe, sharing trends and exploring issues affecting higher education in their countries and regions. This web-based addition to the information provided in the book allows for student affairs and services professionals to stay up-to-date on new ideas, current events, and additional information on higher education in other countries that are not currently represented in the printed book.

The editors of Supporting Students Globally in Higher Education clearly made an effort to decenter the U.S. perspective on student affairs and services in this book; to some extent they were successful in this effort, but there is still a dearth of voices from the developing world. The majority of chapter authors are from the United States or Canada, and although some have spent significant time working abroad, very few authors are from other countries. Though this is understandable, this limited voice highlights future research needs for the exchange of ideas from the developing world. This book, along with the IASAS website, is striving to correct this by adding short essays and conversations from a variety of countries, with only 9 out of the 23 essays from the Western perspective (e.g., United States, Australia, and within Europe). The remaining essays mostly focus on emerging markets (e.g., China, India, Mexico, Thailand) or the most developed countries on their respective continents (e.g., South Africa, Ghana, and Nigeria representing the continent of Africa). Despite these understandable limitations, we would hope that in time, additional voices and a larger representation from South America, Central America, Asia, the Middle East, and Africa can be explored and shared more widely.

Another strength of this book is Deardorff's chapter on intercultural competence theory; however, one critique of the text is the limited engagement with other theories and models from the field of international education. By focusing primarily on topics related to student affairs and services without positioning those topics within 
the broader work on internationalization, this book misses an opportunity to engage the sizeable existing theory and models of comprehensive internationalization.

Despite these limitations, Supporting Students Globally in Higher Education gives a great introduction to and summary of where the field of student services is in terms of internationalization, and calls on us to learn from each other's perspectives by promoting crossborder collaboration. In all, the book brings together current issues and recommendations for practice from multiple authors on one of the most important trends for the next decade in student affairs and services. 